\section{Contraste oculto: violência, psicopatologia e cultura}

José Paulo Fiks e Andres Santos Júnior. Ed. Casa Leitura Médica; 2009.

José Paulo Fiks e Andres Santos Júnior, ambos psiquiatras com formação psicanalítica, de fato realizaram um trabalho de singular oportunidade. Trata-se de uma compilação com nove capítulos nos quais os autores, tendo como fio condutor os temas da violência e da barbárie analisados em uma perspectiva psicopatológica, exploram com notória familiaridade diversos ícones da cultura clássica, moderna e contemporânea em seu significado estético frente às vicissitudes históricas e contingências do coletivo.

A obra se oferece como um sugestivo roteiro para aqueles que queiram perscrutar as diversas maneiras pelas quais diferentes formas de arte expressam o tema da violência como elemento

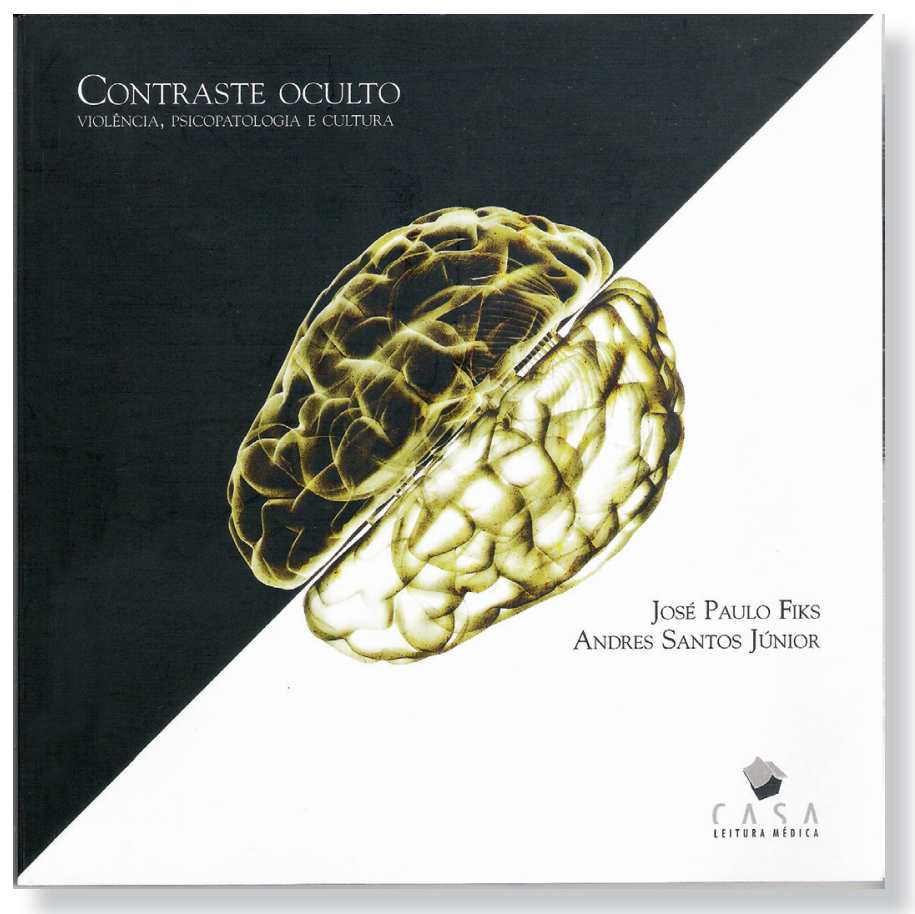

intrínseco à condição humana ao longo da história da arte e da cultura pop. Os autores perscrutam o ímpeto destrutivo inerente à condição humana desde a mitologia grega até as produções dramatúrgicas mais recentes (destaque para o cinema), estabelecendo distinções conceituais, discorrendo sobre possíveis articulações causais de seus elementos e encadeando tópicos de neurociência e de cultura com uma fluência agradável e instigante. Não que a expressão artística dessas nuances sirva para delimitar conceitos psicopatológicos propriamente ditos - os próprios autores são enfáticos em nos dissuadir da tentação -, mas o texto expõe uma coletânea de construtos estéticos que, nas diferentes expressões artísticas, do pop ao clássico, da música à literatura, revelam e ilustram o imaginário coletivo em dimensões relacionadas à representação da violência e de suas consequências traumáticas, tanto em vítimas como em agressores. O próprio contraste entre estas condições é relativizado com base no testemunho da arte e em evidências neurobiológicas recentes. Claro que a composição desse mosaico não poderia deixar de ser provocativa. Embora não constitua análise sistemática e tampouco a profundidade seja pretensão dos autores, os capítulos constituem um feliz encadeamento de colagens no qual os próprios autores assumem que escreveram o livro "para descontentes, encrenqueiros e insatisfeitos".

Em que pese a sugestão, algumas provocações podem ser retribuídas. Embora esta seja uma crítica algo pedante, o texto desafia um problema de natureza epistemológica posto desde os textos metapsicológicos e sociais de Freud, ou seja, o problema de transpor temas relativos à subjetividade individual para o entendimento de manifestações históricas ou de âmbito coletivo (e vice-versa). A título de exemplo, é possível que o caráter imiscível dessas concepções tenha representado uma das principais limitações da hermenêutica freudo-marxista de Frankfurt (leiase Adorno, Horkheimer, o primeiro Habermas etc.). Outra crítica, essa absolutamente pertinente: afinal de contas, por que cargas d'água não foram dedicadas pelo menos algumas linhas ao genioso Anibal "canibal" Lecter?

De resto, leitura agradável, ricamente ilustrada, destemida e instigante. Dá vontade de rever o já visto ou de correr atrás do não visto ou escutado.

Paulo Clemente Sallet Instituto de Psiquiatria, Hospital das Clínicas, Faculdade de Medicina, Universidade de São Paulo (USP), São Paulo (SP), Brasil 